\title{
A STUDY OF ESTIMATING THE AMOUNT OF CORROSION TO STEEL PLATES OF OIL STORAGE TANKS IN BAI-HASSAN OIL FIELD IN KIRKUK
}

\author{
AHMED SAMIR ANWAR \& MOHAMMEDTAHER M. SAEED MULAPEER
}

Lecturer, Department of Mechanical \& Mechatronics, College of Engineering, University of Salahaddin-Erbil, Iraq

\begin{abstract}
The steel plate Grade S355GT st52 of KAR Group is used for the construction of storage tanks for oil works in KAR storage tanks. In this study we have found out the chemical and physical changes of the welded steel plate after the damage happened due to the ISIS attack in Bai-Hassan in Kirkuk. After receiving the samples of burned and heated steel plates, it has been machined the samples for tensile, hardness, chemical analysis and microstructural analysis. The plate thickness is reduced in certain areas of the plate due to oxidation at high temperatures of the material occurred especially at the weld area and the thickness of the plate is found to be between 13 and $18 \mathrm{~mm}$. Due to the coarsening of the microstructure and the development of Widmanstatten ferrite which is a weak and undesirable microstructure has been seen in the microstructure of this steel. Extraction of Acoustic Emission (AE) signal features (magnitude, power, hit, time period and rise period varies with time and the relation between them) will use for identifying the corrosion level and diagnosing the type of corrosion of the steel plates of oil storage tank, and moreover to measure the corrosion severity of the complete storage tank.
\end{abstract}

KEYWORDS: Steel Plates of Oil Storage Tank, Steel Corrosion \& Acoustic Emission

Received: Jul 09, 2019; Accepted: Jul 29, 2019; Published: Sep 25, 2019; Paper Id.: IJMPERDDEC20191

\section{INTRODUCTION}

Numerous engineering structures like seaward oil plants or oil stockpiling tanks are built by utilizing the high plate-like component and are liable to erosion and exhaust harm during their working period. Proficient scanning of the robustness of huge zones of such structures from a solitary observing area could be accomplished from a guided ultrasonic wave arrangement. The pressure in guided waves is conveyed along the structure thickness and can proliferate over long distance. When any auxiliary imperfections such as extreme decrease in thickness because of consumption setting occurs, the guided wave mode is dissipated and some portion of its power gets reflected back in the direction of observation zone. With this setup, an effective NDT and observation of enormous engineering structures can be realized.

During 1990, the contamination brought about by unrefined petroleum spills was come up as a serious and important issue. The standards and guidelines on tankers was proposed by the International Maritime Organization (IMO) have turned out to be progressively rigorous. In this manner, the two-fold structure development is needed as a body enhancement measure and the demonstration of assurance criteria for raw petroleum tanks as an anticorrosion value. According to the security requirement for raw petroleum tanks of tanker boats executed by 2013, the anticorrosion steel is suggested by the Japan and was affirmed without precedent for the ship company as a corrosion resistant measure and can be substituted for painting. 
The well-known erosion sorts are setting and uniform erosion, particularly setting erosion in low carbon steel. Low carbon steels are broadly utilized as a primary component in open stockpiling tank, and it plays a unique role in storing and conveyance of raw petroleum and its origin. Be that as it may, over $80 \%$ of the tanks are ceased, steel aperture and spillage incidents are due to tank steel erosion. This causes intensive effect on the surrounding, wellbeing and security, and causing a large number of perils and fiascos. Subsequently, the erosion in capacity tank steel has gained an ever increasing number of awareness in previous years [1-3].

The erosion harm of steel plates of oil storage tank is an extremely muddled stage [4,5]. Ions such as $\mathrm{Na}^{+}, \mathrm{Ca}^{2+}$, $\mathrm{SO}_{4}{ }^{2-}, \mathrm{Cl}^{-}, \mathrm{S}_{2}^{-}$, and dissolved $\mathrm{O}_{2}, \mathrm{H}_{2} \mathrm{~S}, \mathrm{CO}_{2}$ in the sedimentary water on steel plates of oil storage tank can penetrate the neighborhood crumbling anticorrosion sealing and results in setting erosion in the coating [6-8], and causes puncturing and spillage. Thus, intermittent investigation is important to anticipate decimation of steel plates of oil storage tank erosion. Few traditional testing methods like attractive motion density spillage evaluation and remote field eddy current testing have been used to find and depict the deformities [9-12]. Be that as it may, these procedures need a lot of operation intrusion and arrangement, for instance, opening and wiping out the tank. Subsequently, low cost and on-line experimentation methods are required for distinguishing and assessing dynamic imperfections of steel plates of oil storage tank. The acoustic emission strategy is considered to meet the necessities of on-line review system and has been developed as a prominence approach [13-18].

Acoustic emanation is a NDT strategy which is characterized by American Society for Testing of Materials (ASTM) where the temporary flexible signals are produced by the quick power delivery from restricted inputs inside a material, called the pressure signal discharge or small scale seismic action. It is broadly utilized to observe procedure of plastic malformation, stress splitting and erosion destruction. Removing and dissecting the successful sign to measure the highlights of AE sources is the restriction of $\mathrm{AE}$ on location examination. Different scientists have demonstrated that the AE signs are firmly associated with erosion factor and electrochemical process. Fregonese et al., [7] explored the inception and spread phase of setting erosion for hard steel and received hydrogen bubbles full AE sign in spreading phase. Mansfeld et al., [19] related the setting erosion pace of aluminum composites with AE function. Same ideas were already exhibited by Yuyama and Yamada [20, 21, 22 \& 23]. Darowicki et al., [24, 25] got the setting erosion capability of aluminum via the aggregate dissemination work of the likelihood of setting erosion event based on AE information. Alvarez and Lapitz [26, 27 \& 28] result affirmed the AE function during the passing of trans-granular stress erosion splitting as more than the $\mathrm{AE}$ action in the inter-granular stress erosion breaking stage. Prateepasen et al., [29, 30 \& 31] allocated AE for hydrogen bubble cavitations and identified the air bubbles recurrence condition. More number of AE works had been done centered around setting erosion and SCC of the hard steel and aluminum compounds [32, 33 \& 34]. Above all only few investigations had been completed on the setting erosion of carbon less steel. In this unique situation, the purpose of the proposed work is to estimate the amount of damage happened to the steel plates of oil storage tanks in Bai-Hassan oil field in Kirkuk due to an ISIS attack.

\section{EXPERIMENTAL PROCEDURE}

\subsection{Materials}

Sample materials were broken into little pieces by utilizing wire-terminal cutting strategy with sizes of $2.9 \times 2.9 \times 0.2 \mathrm{~cm}^{3}$. Steel constitution is provided in Table 1. The uncovered areas were cleaned with a silicon carbide sheet progression upto 1200 coarseness. The samples are flushed using de-ionized (DI) water and $\left(\mathrm{CH}_{3}\right)_{2} \mathrm{CO}$ and liquor, and then dehydrated in a desiccators and gauged, named and kept away. 
Table 1: Chemical Composition: Steel Grade S355 st52

\begin{tabular}{|c|c|c|c|c|c|c|c|c|c|c|c|}
\hline Elements & $\mathrm{C} \%$ & $\mathrm{Si} \%$ & Mn\% & $\mathbf{P} \%$ & $\mathrm{S \%}$ & $\mathrm{Cr} \%$ & $\mathrm{Cu} \%$ & $\mathrm{Ni} \%$ & V\% & Al\% & $\mathrm{Fe} \%$ \\
\hline Concentration & 0.185 & 0.435 & 1.50 & 0.022 & 0.0193 & 0.0105 & 0.026 & 0.010 & 0.0028 & 0.055 & 97.65 \\
\hline $\begin{array}{l}\text { Reference } \\
\text { Values } \\
\text { S355GT Steel }\end{array}$ & $\begin{array}{c}0.22 \% \\
\max \end{array}$ & $\begin{array}{c}0.55 \% \\
\max \end{array}$ & $\begin{array}{c}1.6 \% \\
\max \end{array}$ & $\begin{array}{c}0.05 \% \\
\max \end{array}$ & $\begin{array}{c}0.05 \% \\
\max \end{array}$ & $\begin{array}{c}0.3 \% \\
\max \end{array}$ & $\begin{array}{c}0.55 \% \\
\max \end{array}$ & $\begin{array}{c}0.4 \% \\
\max \end{array}$ & $\begin{array}{c}0.04 \% \\
\max \end{array}$ & & Balance \\
\hline
\end{tabular}

\subsection{Electrochemical Device}

Electrochemical calculations were done on a PAR 2273 electrochemical platform created by AMETEX. The least output current is $1.2 \mathrm{fA}$ and the least voltage requirement is $2.5 \mu \mathrm{V}$. A special 3 electrode framework is established. The required specimens are the operating electrode (WE), electrochemical voltage is calculated with the saturated calomel reference electrode (SCERE) and a platinum sheet as a counter electrode.

\subsection{Acoustic Emission Surveillance System}

AE system consists of piezoelectric sensor (VS150-RIC from Valley integrated with preamplifier: $34 \mathrm{~dB}$ gain) and acquisition device AMSY-5 from Germany Valley System GmbH. The AMSY-5 was a completely digitized multiple filter AE computation framework to obtain AE variables. The frequency reaction graph of the sensor was depicted in figure 1. AE inception was set at $30.2 \mathrm{~dB}$ based on backend noise severity and channeled by BPF from $25 \mathrm{kHz}$ to $850 \mathrm{kHz}$.

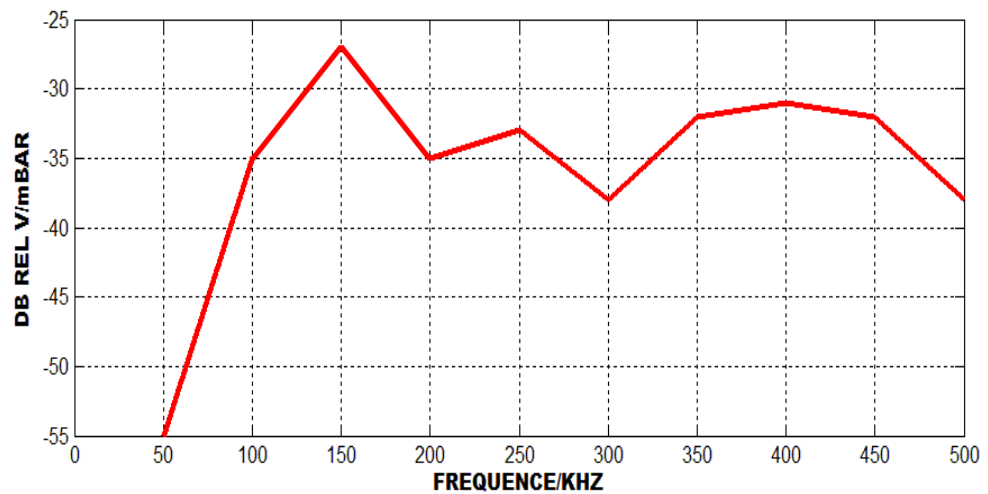

Figure 1: AE Sensor's Frequency Response.

\section{RESULTS \& DISCUSSIONS}

The erosive liquid is stored in a glass cell upto $80 \%$ of the compartment stature, leaving it for 2 hours until the liquid become fixed. At that point, the open circuit potential was estimated and its graph is depicted in figure 2.

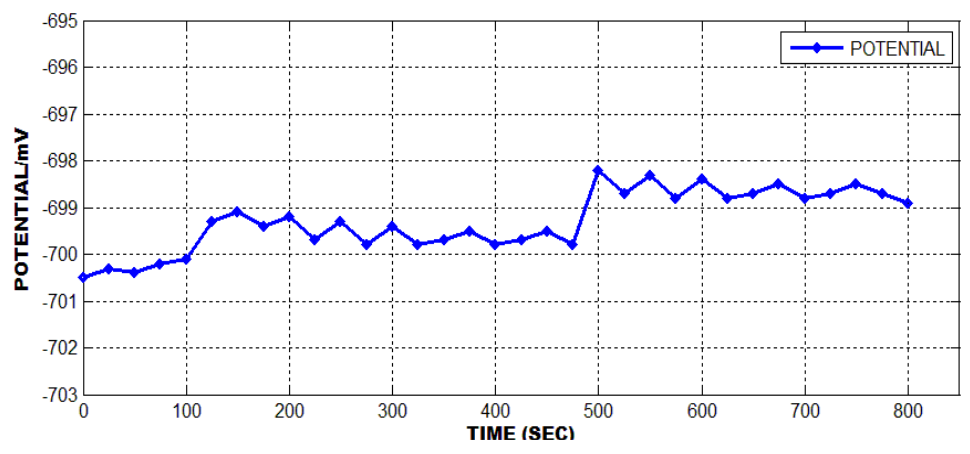

Figure 2: Open Circuit Potential Decreases for Low Carbon Steel (3\%) NaCl Solution at pH 2.0. 
The variation in OCP was under $1 \mathrm{mV}$ for more than $10 \mathrm{~min}$, which showed that the erosion have arrived at a steady state. The consequence of erosion procedure in the carbon steel is demonstrated as follows. The erosion procedure of metal involves an oxidation and decrease response.

Anode response:

$F e \rightarrow F e^{2+}+2 e^{-}$

The ferrite ion is not steady and quickly gets oxidized to ferric ions as below:

$F e^{2+} \rightarrow \mathrm{Fe}^{3+}+\mathrm{e}^{-}($

Cathode response:

$2 \mathrm{H}^{+}+2 e^{-} \rightarrow \mathrm{H}_{2}$
$\mathrm{O}_{2}+4 H^{+}+4 e^{-} \rightarrow 2 \mathrm{H}_{2} \mathrm{O}$

Total reaction:

$\left(F e^{3+}+3 C L^{-}\right)+3 \mathrm{H}_{2} \mathrm{O} \rightarrow \mathrm{Fe}(\mathrm{OH})_{3}+3 \mathrm{H}^{+}+3 C L^{-}$

The chlorine particles get assimilated on the material external side and attack the neighborhood deformity of detached layer, and cut the layer. All such responses prompt to the creation of $\mathrm{FeCl}_{2}$ and $\mathrm{FeCl}_{3}$ that can relocate ceaselessly from the assemblage to the arrangement.

AE identification was performed all the while in order to store the acquired information. In the quickened erosion stage, the peeling and breaking of oxidized layer caused by chlorine particle, the deposit and grating of erosion items are likewise create AE signals.

\subsection{AE Sign Features in Potential-Dynamic Polarization}

The potential dynamic polarization can be seen up to the scope of $0.25 \mathrm{~V}$ (Vs OCP) $\sim 1.60 \mathrm{~V}$ with an output pace of $0.50 \mathrm{mV} / \mathrm{s}$, and at the same time the AE information was also procured. The potential dynamic polarization graph is depicted in figure 3 . The external side of the sample started to oxidize and slender anode oxide film was framed, when the sample was energized to a high potential. The flow thickness decreased altogether for the layer opposition when potential arrived at $0.3 \mathrm{~V}$. At this level, the new anode oxide layer arrangement was more than the old layer disintegration rate. Thus, the entire metal area was continuously closed by the oxide layer, and the density of oxide layer expanded with respect to time. With potential expansion, the dynamic chloride particles are adsorbed and assembled on the limited oxide layer surface. The chlorine particles occupy the limited deformities area and quickened enormously the layer disintegration. The layer was annihilated locally and the metal array was presented to generate the disintegration functioning point. The little disintegration was labeled as atomic pitting. The oxide layer of carbon less steel damage was seen in the voltage range of $0.8-1.0 \mathrm{~V}$ via potential dynamic polarization tests.

The AE hit dissemination with period has four phases relating to potential dynamic polarization graph. The AE hits indicated great stability with I, II, III and IV level were appeared in figure 4. In the Ist level, there was not many AE sign watched, and the metal started to disintegrate and the pace of oxide layer arrangement was generally low. Both force and movement of AE were at less level from 500 to 2000s. AE sign started to increase forcefully in the level II, a large portion of the AE sign created by the layer arrangement and layer disintegration practices, and the new layer develop step by step and ended up by overwhelming. It is demonstrated that the normal hit rate expanded quickly to 1.2 hits/s. 


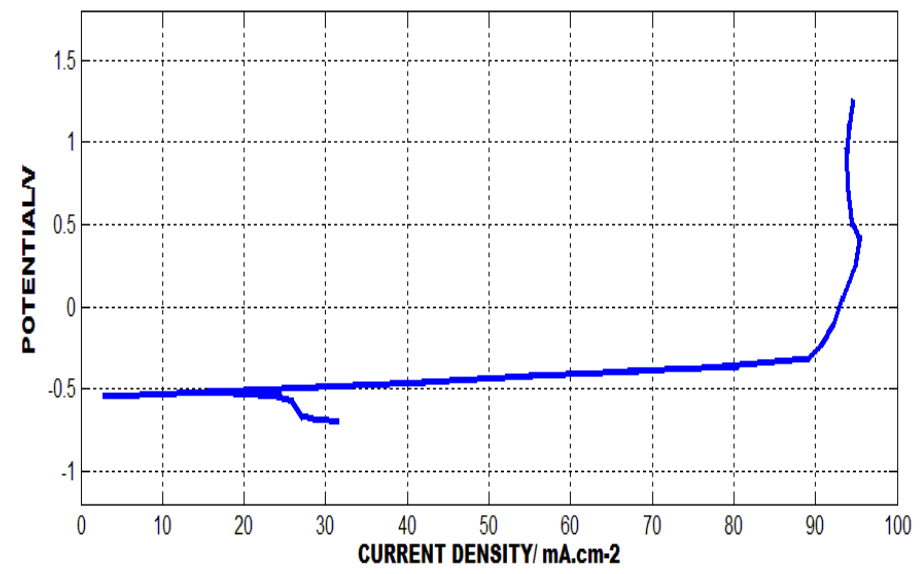

Figure 3: Potential Dynamic Polarization Graph at Monitoring Rate 0.5 m V/s of Low Carbon Steel.

The AE sign magnitude dissemination with period was given in figure 5. From 2000 to 2700s, the AE magnitude appropriated from 32 to $45 \mathrm{~dB}$, AE force was more grounded in level I. From 2700 to 3600s, AE sign diminished altogether, and both AE power and movement were less than the level II. It was demonstrated that the oxide layer had closed all metal openings in this level. The oxide layer could isolate the metal array from erosion arrangement and thwarted the metal particles from legitimately going into the arrangement. After $3600 \mathrm{~s}$, AE movement expanded forcefully, the greatest $\mathrm{AE}$ hit rate arrived at 8 hits/sec. In the mean time, $\mathrm{AE}$ power is additionally expanded, the highest $\mathrm{AE}$ magnitude was up to $60 \mathrm{~dB}$. AE sign was concentrated more grounded than the initial three phases. The outcomes demonstrated that the oxide shed from metal array are burst, the setting atoms are developed to be numerous visual pits and the erosion items are accumulated in the region of the pit. These pits are created as impeded cell with the development of a metal top at adequate rate. The hydrolysis of $\mathrm{Fe}^{3+}$ particles inside the blocked cells raised the nearby $\mathrm{H}^{+}$fixation, and the relocation of $\mathrm{Cl}^{-}$particles and the development of $\mathrm{H}^{+}$particles made the cells increasingly acidic. The blocked cells were kept functioning and the pits became further.

As appeared in figure 6, at the last phase of polarization test, bunches of high abundancy AE sign rose. The sign magnitude is more than $50 \mathrm{~dB}$ and the term period is under $80 \mu \mathrm{s}$. It further shows that the setting erosion is in a high dynamic stage in this level.

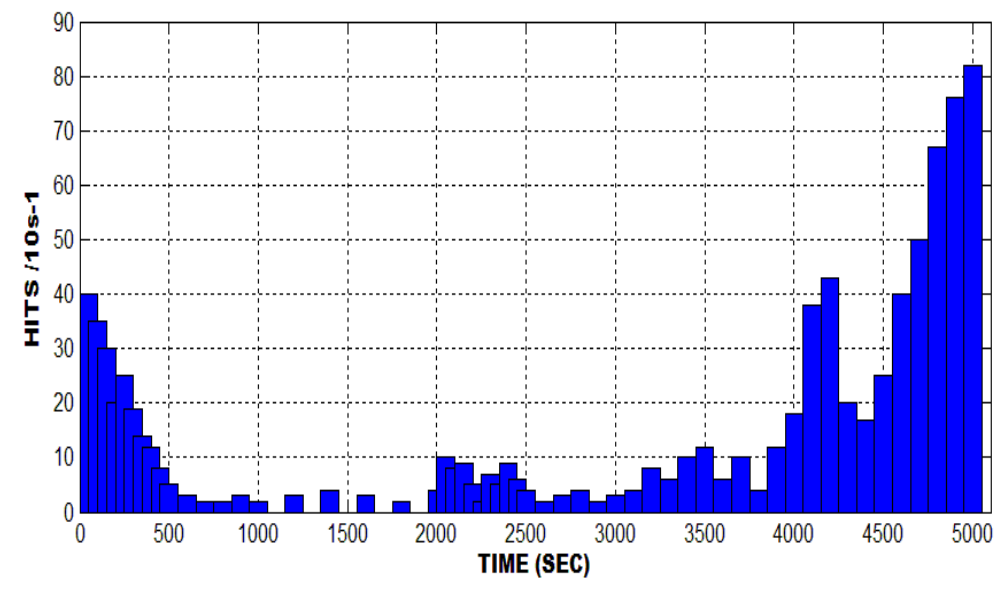

Figure 4: AE Hit Spread with Time (/10s). 


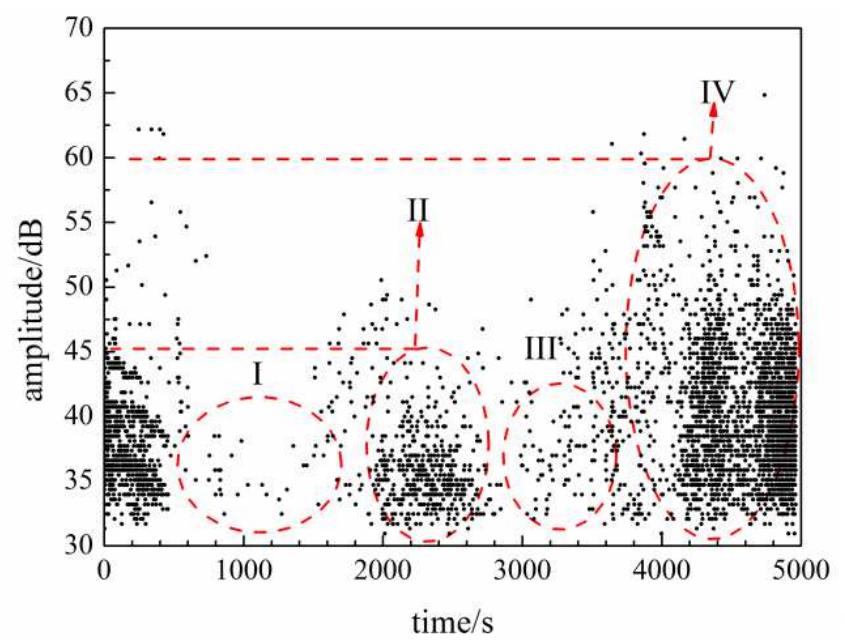

Figure 5: AE Signal Magnitude Varies with Time under Dynamic Potential Polarization.

\subsection{AE Signal under Static Potential Polarization}

As indicated by the potential dynamic polarization graph, the voltage was maintained at $1 \mathrm{~V}$ by a potentiostat to upkeep fixed setting erosion on the sample. The static potential polarization test kept for 2 hours, and obtained the AE sign at the same time. As appeared in figure 7, an enormous number of AE signs are recognized all through the entire erosion activity, the AE movement and force were at an abnormal state. Particularly in the time of 900-1200s and after $3600 \mathrm{~s}$, both the AE action and force are expanded altogether, and some AE signal magnitude surpass at 65 $\mathrm{dB}$, and the high period signal over $100 \mu \mathrm{s}$ rose often in the double locales. From 900 to $1200 \mathrm{~s}$, the peeling, contracting and breakage of the oxide layer produced more AE signal, went with more span signal. After the crack of the oxide layer, the AE movement diminished generally, setting erosion was in the inception level, additionally labeled as acceptance period. After 3200s, The AE movement and force expanded once more, it represented that the erosion items started to peel, the erosion and splitting in erosion items layers brought about high span signal. The AE hits connection with magnitude demonstrated that AE magnitude for the most part ran from 35 to $45 \mathrm{~dB}$ in figure 8 , and disseminated all through the entire accession time.

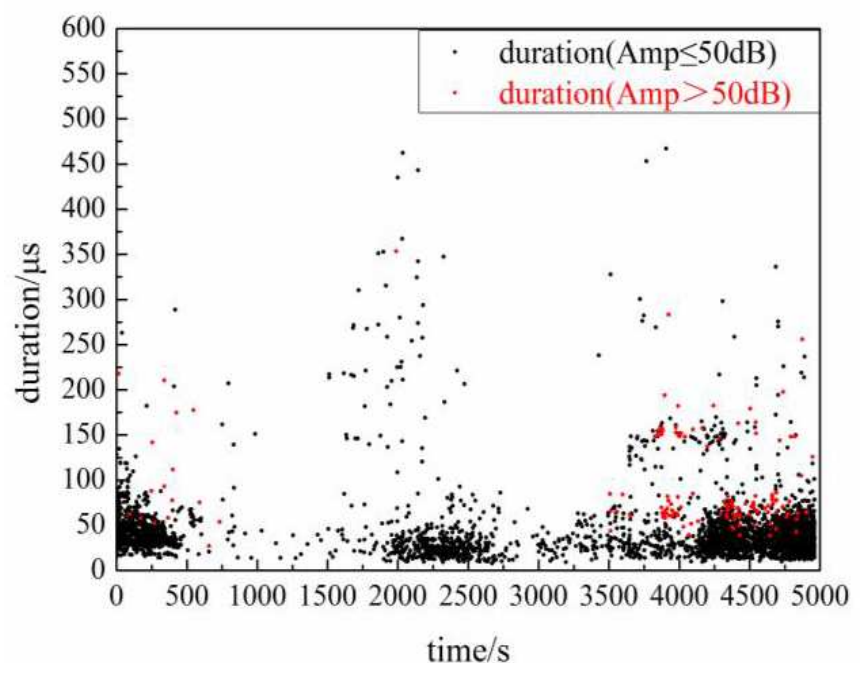

Figure 6: AE Hit Period Sparse with Time under Dynamic Potential Polarization. 


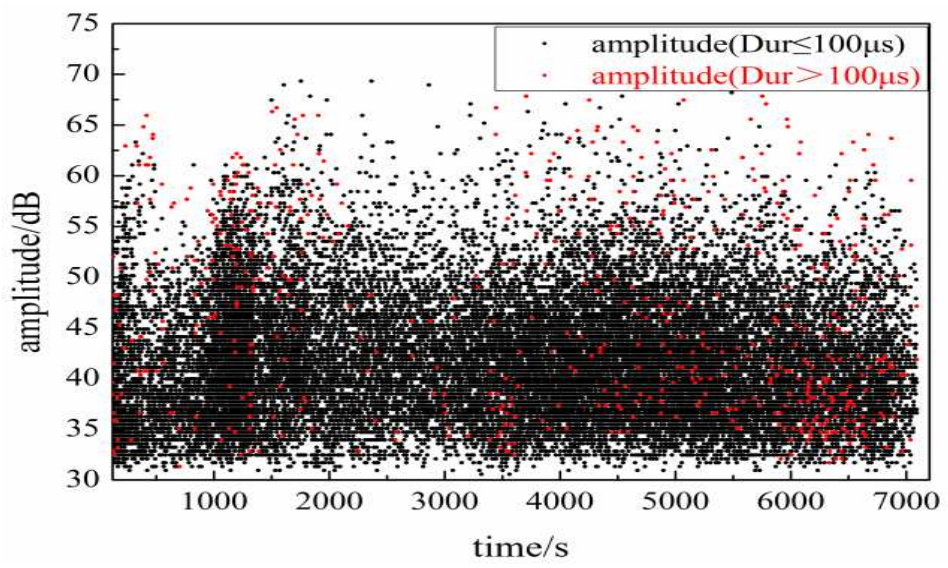

Figure 7: AE Signal Variation with Time under Static Potential Polarization.

To affirm the attributes of the AE signals at the time of setting erosion process, relationship study among AE hits, vitality with time was given in figures 9 and 10. The AE hits fundamental pinnacle esteem corresponds to the sign span of $35-55 \mu \mathrm{s}$, and it is clear that the subsequent hits pinnacle at 150-170 $\mu$ s by enhancing some portion of the curve in figure 9. The fundamental pinnacle worth of AE signal vitality corresponds to the sign span of 50-80 $\mu$ s while the subsequent vitality pinnacle is at 160-180 $\mu$ s. Contrasting the two images, the time period of AE hit pinnacle was not aligned with AE vitality pinnacle. This showed that amid the AE sign produced by setting erosion, the highest vitality sign will have a high span. The event of the primary and its successive pinnacle manifested that most of AE hits were produced by pit development and distribution and these sign had generally a brief span time, in the mean time AE hit discharged from oxide layer break took a little part, however, the sign vitality and time were relative higher and brought about a slight change in the vitality crest towards the more extended time. This summary coincides with the outcomes procured by Parteepasen and Jirarungsatian [29, 35]. Be that as it may, in their examination, they did not study about the relationship between $\mathrm{AE}$ hit and time period, and connection between AE vitality and time period. AE hit and vitality can straight forwardly mirror the action of the AE source, and its vitality variation mirror the discharged vitality from neighborhood erosion and these may be useful for perceiving the distinct erosion practices. Figures 9 and 10 affirmed that these two sorts of sign were predominantly produced by the pit development and layer breakdown.

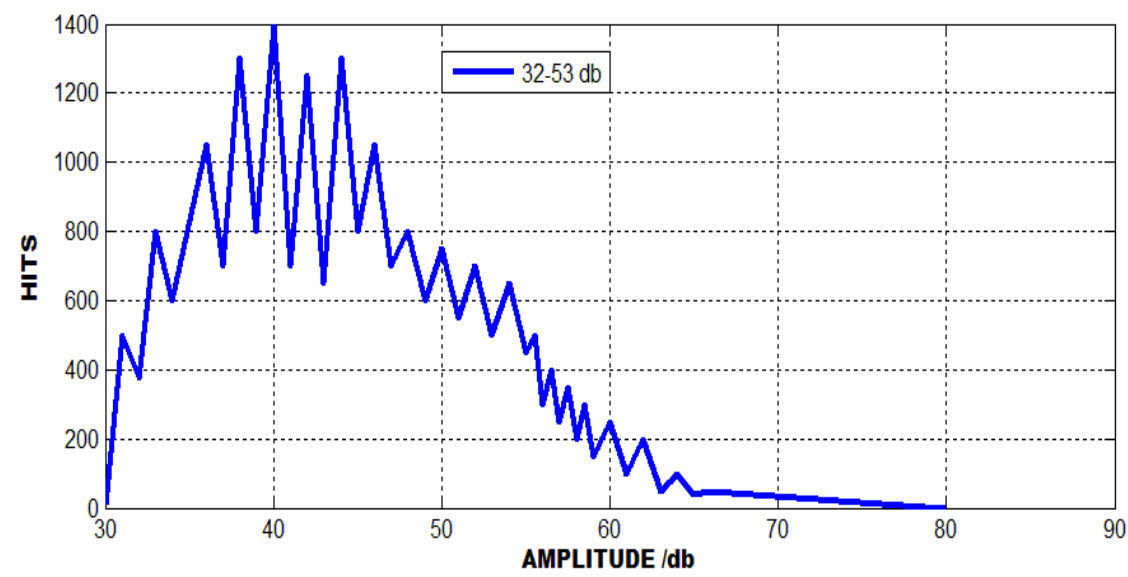

Figure 8: AE Hit Correlation with Magnitude. 


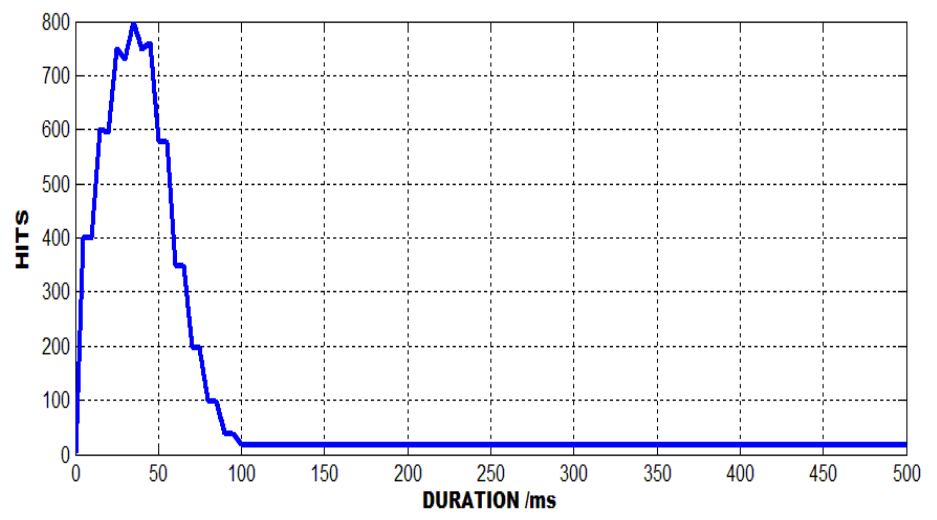

Figure 9: AE Hit with Duration.

In light of the above investigation, there exist three average AE sources in setting erosion; peeling and break of the oxide layer, the development and engendering of the pit, rubbing and splitting in erosion items layer. The investigation of clustering of the $\mathrm{AE}$ source was appeared in figure 11. It is demonstrated that the moderately long time sign was discharged from oxide layer crack and erosion items exercises. An enormous number of prevailing AE signs with brief length were created by pit development and spread.

The outcome is affirmed from the pits perception after the test finished by utilizing Zeiss Axio 3D confocal metallographic magnifying instrument. The surface morphology and pit picture samples were appeared in figure 12 . The 3D surface geology describes the morphology and the sizes of the pit. An enormous amount of honeycomb pit circulated on the sample outside, and the vast majority of the pit profundity was of $250 \mu \mathrm{m}$ by the factual investigation, that further affirmed the surface sample was experiencing an extreme setting erosion.

\section{Test \#1: Tensile Properties}

\section{Base Material}

Machined tensile specimens - round specimens; do $=6.25 \mathrm{~mm}$ and $\mathrm{L}_{\mathrm{o}}=50 \mathrm{~mm}$.

The results of average of three samples:

$$
\begin{array}{ll}
\text { Ultimate Tensile strength }=506 \mathrm{MPa} & \text { required }>490 \mathrm{MPa} \\
\text { Yield strength }=345 \mathrm{MPa} & \text { required }>355 \mathrm{MPa} \\
\text { Elongation }[\mathrm{Lo}=50 \mathrm{~mm}]=30 \% & \text { required }>21 \%
\end{array}
$$

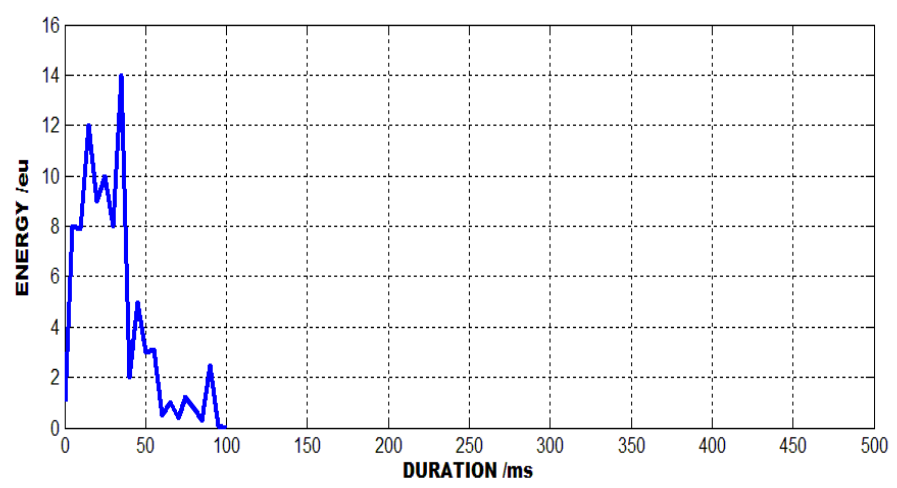

Figure 10: AE Energy Varies with Time (1eu=10-14 V2s). 


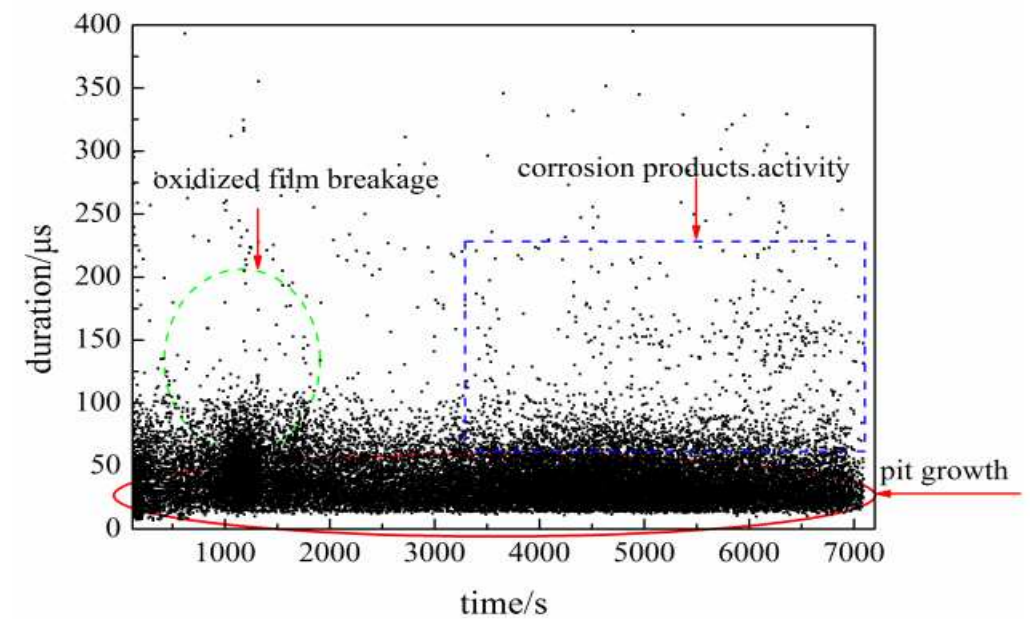

Figure 11: AE Hit Duration Varies with Time under Static Potential

Polarization.

\section{Weld Area: Samples made Traverse to Welding Line}

Machined tensile specimens - round specimens; do $=6.25 \mathrm{~mm}$ and $\mathrm{L}_{\mathrm{o}}=50 \mathrm{~mm}$.

The results of average of three samples:

Ultimate Tensile strength $=453 \mathrm{MPa} \quad$ required $>490 \mathrm{MPa}$

Yield strength $=354 \mathrm{MPa} \quad$ required $>355 \mathrm{MPa}$

Elongation $[\mathrm{Lo}=50 \mathrm{~mm}]=18 \% \quad$ required $>21 \%$

Fracture location: within the weld area.

\section{Test \#2: Hardness Test}

Brinell hardness HB30 profile of the base and the weld material has been done as shown in figure 13. The hardness value ranges between $89 \mathrm{~kg} / \mathrm{mm}^{2}$ in the weld cup zone or point \#1 as shown in the figure; and $139 \mathrm{~kg} / \mathrm{mm}^{2}$ in point \#20. So, we observed softening of the weld zone due to the heat received by the plate. The hardness of the base plate away from the weld area is about $139 \mathrm{~kg} / \mathrm{mm}^{2}$.

(a)

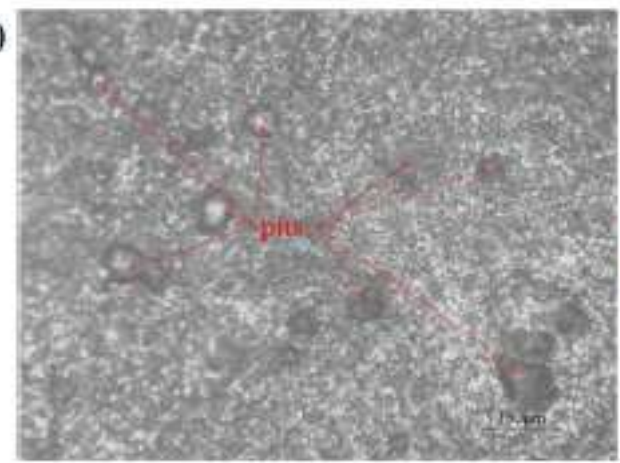

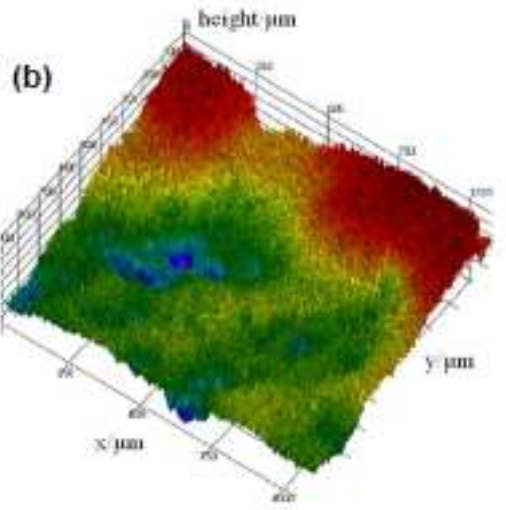

Figure 12: Specimen Surface Morphology after Potentiostatic Verification 2 Hours in 3\% NaCl Solution at pH2.0 (a) Surface Morphology $(\times 100)$ and (b) 3D Pits Image (×200). 


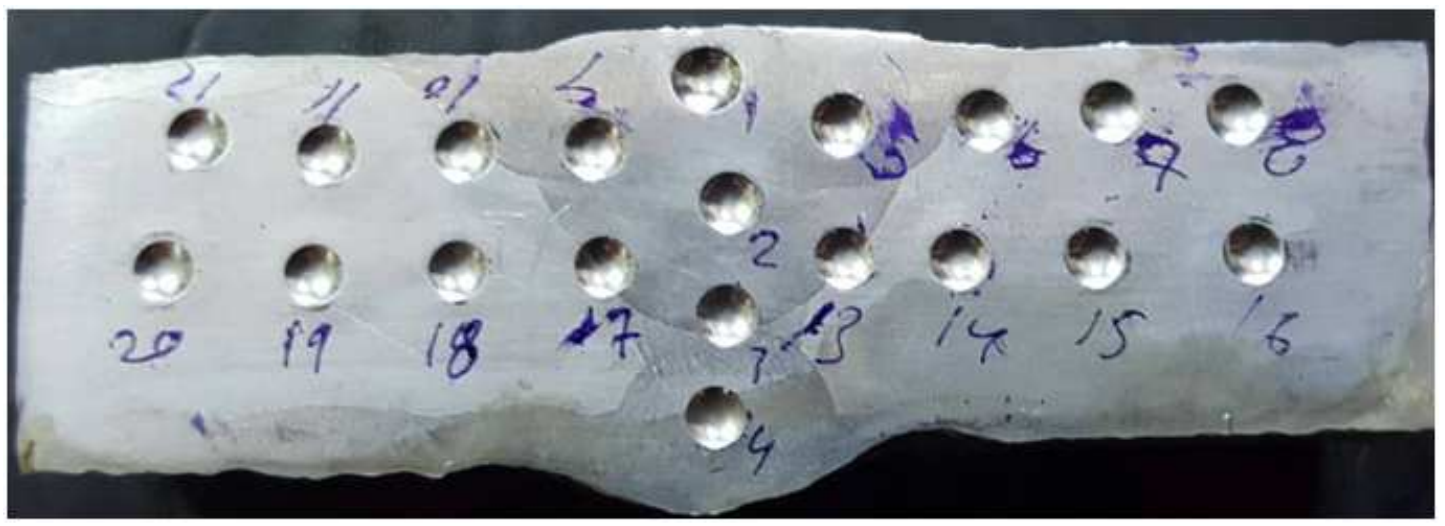

Figure 13: Hardness Measurement throughout the Weld Zone.

\section{CONCLUSIONS}

This article is indented for analyzing the amount of damage happened to the steel plates of oil storage tanks by utilizing the AE strategy. After performing detailed examinations on the $18 \mathrm{~mm}$ steel plate grade S355GT-St52, the following conclusions were drawn.

Plate thickness is reduced to about $13 \mathrm{~mm}$ in certain areas of the plate due to oxidation at high temperatures and softening of the material occurred especially at the weld area due to the coarsening of the microstructure and the development of Widmanstätten ferrite which is weak and undesirable microstructure. Softening of the base metal is attributed to the development of a new microstructure consisting of ferrite matrix and pearlite segregation in the form of pearlite bands. Also, some of the pearlite may be undergone dissociation and spheriodized cementite is observed in certain areas of the microstructure of the base metal.

Setting erosion of steel plate of capacity tank can create rich acoustic outflow. The AE sign traits portray each phase of setting erosion perfectly. After eliminating the hydrogen bubble burst sign, the shedding and break of the oxide layer, development and spread of pits, heaping up of erosion items, rubbing and splitting in erosion items layers are the fundamental AE source. Pits development AE sign span is under $80 \mu \mathrm{s}$, but oxide layer crack and the grating in the erosion layer signal period is in the range of 130-170 $\mu$ s. The magnitude of AE signal in the steel plates of oil storage tank setting is nearly less than $65 \mathrm{~dB}$, and is centered around $32-53 \mathrm{~dB}$. AE sign magnitude from the oxide layer damage and erosion items splitting is somewhat high. It will be of good assistance on identifying the erosion seriousness and distinguishing the type of erosion of the AE on-line steel plates of oil storage tank review and to survey the erosion level of the entire oil storage tank.

\section{REFERENCES}

1. J. Shuai, K. Han and X. Xu, J. Loss. Prevent. Proc., 25 (2012) 166

2. F. Liu, X. Guo, D. Hu, W. Guo and N. Jin, Nondestruct. Test. Eva., 25 (2010) 45

3. J. X. Zhu, Journal of Materials Protection, 42 (2009) 56

4. Latifa, Lemtaouch., Yang, K. J., \& Xu, R. R. (2014). Economic growth and $\mathrm{CO}_{2}$ emissions nexus in Algeria: a co-integration analysis of the environmental Kuznets curve. Int J Econ, Commer Res, 4(4), 1-14

5. Y. Zhou, M. Liu, X. Ni, D. Chen and W. Wei, Advanced Materials Research, 317 (2011) 66

6. A. Zagorski, H. Matysiak, O. Tsyrulnyk, O. Zvirko, H. Nykyforchyn and K. Kurzydlowski, Mater. Sci., 40 (2004) 421 
7. M. Fregonese, L. Jaubert and Y. Cetre, Prog. Org. Coat., 59 (2007) 239

8. M. Fregonese, H. Idrissi, H. Mazille, L. Renaud and Y. Cetre, Corros. Sci., 43 (2001) 627

9. X. Zhao and J. Jiang, China Safety Science Journal, 15 (2005) 104

10. Rao, N. D. P., Krishna, M. M., Prasad, B. A., \& Murthy, P. The effect of thermal barrier coating on exhaust emissions and combustion characteristics of diesel engine with rice brawn oil based biodiesel. International Journal of Research in Engineering and Technology, ISSN (E), 2321-8843

11. C. Jomdecha, A. Prateepasen and P. Kaewtrakulpong, NDT \& E Int., 40 (2007) 584

12. A. R. Ramirez, J. S. D. Mason and N. Pearson, NDT \& E Int., 42 (2009) 16

13. N. Kasai, Y. Fujiwara, K. Sekine and T. Sakamoto, NDT \& E Int., 41 (2008) 525

14. N. Kasai, K. Sekine and H. Maruyama, Journal of the Japan Petroleum Institute, 47 (2004) 19

15. J. F. Chen, H. S. Bi, Q. Wang, A. Q. Wang, H. Sheng and H. X. Rong, Advanced Materials Research, 807 (2013) 2652

16. H. S. Bi, Z. L. Li, Y. P. Cheng, Isaac and J. Wang, Advanced Materials Research, 694 (2013) 1167

17. Singh, R. R., Gaikwad, Abhishek., Singh, S. S., \& Singh, V. P. (2008). Comparison of mechanical properties of medium carbon steel with dual phase steel. International Journal of Mechanical Engineering, 4, 1-8

18. M. Riahi, H. Shamekh and B. Khosrowzadeh, Russ. J. Nondestruct, 44 (2008) 436

19. M. Riahi and H. Shamekh, Russ. J. Nondestruct, 42 (2006) 537

20. A. V. Sokolkin, I. Y. Ievlev and S. O. Cholakh, Russ. J. Nondestruct, 38 (2002) 113

21. A. V. Sokolkin, I. Y. Ievlev and S. O. Cholakh, Russ. J. Nondestruct, 38 (2002) 902

22. A. M. Reyman, E. V. Krotov and A. D. Mansfeld, Proceedings of the Society of Photo-Optical Instrumentation Engineers, 2 (2001) 109

23. S. Park, S. Kitsukawa, K. Katoh, S. Yuyama, H. Maruyama and K. Sekine, Mater. Trans., 46 (2005) 2490

24. N. Kasai, K. Utatsu, S. Park, S. Kitsukawa and K. Sekine, Corros. Sci., 51 (2009) 1679

25. S. Park, S. Kitsukawa, K. Katoh, S. Yuyama, H. Maruyama and K. Sekine, Mater. Trans., 47 (2006) 1240

26. S. Yuyama, M. Yamada, K. Sekine and S. Kitsukawa, Mater. Eval., 65 (2007) 888

27. K. Darowicki, J. Orlikowski, A. Arutunow and W. Jurczak, J. Electrochem. Soc., 154 (2007) C74

28. Lele, Upendra. (2016). Impact of Oil Prices on Revenue Growth and Profitability of Saudi Listed Companies in Non-Financial Sectors. International Journal of Management, Information Technology and Engineering, 4(6), 13-20

29. S. Krakowiak and K. Darowicki, J. Solid State Electr., 13 (2009) 1653

30. P. Lapitz, J. Ruzzante and M. Alvarez, Corros. Sci., 49 (2007) 3812

31. M. Alvarez, P. Lapitz and J. Ruzzante, Corros. Sci., 50 (2008) 3382

32. M. Alvarez, P. Lapitz and J. Ruzzante, Corros. Sci., 55 (2012) 5

33. A. Prateepasen and C. Jirarungsatian, Corrosion, 67 (2011) 056001

34. C. Jirarungsatian and A. Prateepasen, Corros. Sci., 52 (2010) 187 
35. A. Prateepasen, P. Kaewtrakulpong and C. Jirarungsatean, Advanced Nondestructuve Evaluation, 321-323 (2006) 549

36. M. Boinet, J. Bernard, M. Chatenet, F. Dalard and S. Maximovitch, Electrochim. Acta, 55 (2010) 3454

37. H. Leinonen, T. Schildt, H. Hanninen, Metallurgical and Materials Transactions a-Physical Metallurgy and Materials Science, $42 A(2011) 424$

38. V. Smanio, M. Fregonese, J. Kittel, T. Cassagne and B. Normand, Corros. Sci.,53 (2011) 3942

39. A. Prateepasen, C. Jirarungsatean and P. Tuengsook, Advanced Nondestructuve Evaluation, 321-323 (2006) 545

\section{AUTHOR'S PROFILE}

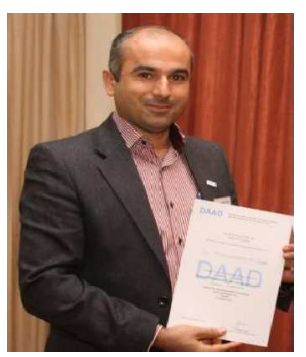

Mohammedtaher M. Mulapeer has received Bachelor of Science-BSc (Mechanical Engineering Department) from Salahaddin University,Erbil,Iraq in 1999, Master of Science MSc (Mechanical Engineering Department) from Salahaddin University, Erbil, Iraq in 2002 and Doctor of philosophy PhD (Mechanical Engineering Department) from Salahaddin University, Erbil, Iraq in 2009. He has more than 20 years of experience in teaching and industry. He is currently working as Head of Mechanical Engineering Department, Salahaddin University 2019, Erbil, Iraq. He is Expert in Material Testing Technologies, Consultant in the field of Welding metallurgy, highly qualified in industrial managements, Consultant in the field of Polymeric materials, Budget Forecasting, Leadership capabilities, Time Management skills, AutoCAD, Matlab, DASYLab and LABView Programs. He has published more than ten papers in reputed international journals. He has attended more than twenty national and international conferences. He is an active member of many professional societies.

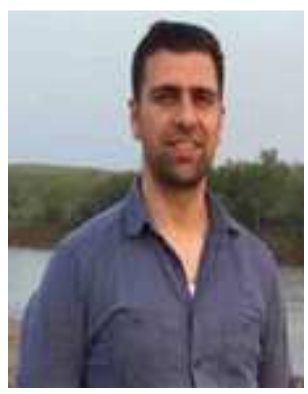

AHMED SAMIR ALEMDAR has received Bachelor of Science-B.Sc (General Mechanical Engineering.) from Salahaddin University, Erbil, Iraq in 2008, Master of Science M.Sc P.E. (Material Science - Construction Engineering Division) from University of Gaziantep, Erbil, Iraq in 2013. He has 10 years of experience in teaching and industry. He is currently working as Lecturer - Consultant Engineer at E.C.B in Mechanical Engineering Department, Salahaddin University, Erbil, Iraq., He has published more than five papers in reputed international journals. He has attended more than ten national and international conferences. He is an active member of many professional societies. 